\title{
Comparison of some characteristic properties of Diyarbakir Orgu cheese produced by traditional and industrial method
}

\author{
Candan CANOZER ${ }^{1}$, Şenol KÖSE ${ }^{1 *}$ (D)
}

\begin{abstract}
Orgu cheese, widely produced and consumed in Turkey's South-eastern Anatolia region, is usually made from sheep's milk. In this study, 15 traditional and 15 industrially produced Orgu cheese samples were compared in terms of chemical, biochemical, mineral content, antioxidant, and antimicrobial activity. While the mineral substance and antioxidant activity values of Orgu cheese samples produced by both traditional and industrial methods were close to each other, it was determined that there were differences in terms of chemical and biochemical content. The mineral content was obtained quite high and antioxidant activity was low in cheese samples. Also, the water-soluble extracts of cheese samples didn't show any antimicrobial activity against Staphylococcus aureus ATCC 29213 and Escherichia coli ATCC 11303. It was detected that the production method and ripening conditions have a decisive effect on some basic characteristics of the examined cheeses.
\end{abstract}

Keywords: Orgu cheese; nitrogen fraction; mineral content; antioxidant activity.

Practical Application: Orgu cheese is a kind of traditional Turkish cheese manufactured from raw or pasteurized milk by scalding of curd in salt water.

\section{Introduction}

Diyarbakir Orgu cheese, one of the registered varieties of cheese, is produced in Turkey's Southeastern Anatolia, especially in the province of Diyarbakir, Mardin, Siirt, Sanliurfa, and Van. However, in recent times it can be easily found and widely consumed all over Turkey and also known as cream cheese or scalding cheese in various locations. Orgu cheese, which is in the form of a braid, and oily, homogeneous, and elastic, is compared to White cheese in terms of its composition, to Circassian cheese in terms of flavor, and Kashar, Abaza and Maraş cheeses in terms of production technology because it includes a scalding stage (Kamber, 2005). However, there are differences in the final shape and maturation of the cheese. Old Kashar, Abaza, and Maras cheeses are offered for consumption after a maturation phase of 2-4 months, while Orgu cheese can also be served freshly (Ozdemir et al., 1998).

Orgu cheese, whose production was first started in Diyarbakır, has spread over wider geography in time, its production technology has been developed industrially and has taken its place as a cheese type consumed in many parts of the country. Thus, it received a Geographical Indication Certificate under the name of "Diyarbakır Orgu Cheese" by the Turkish Patent Institute in 2010 (Hatipoğlu, 2014; Turkey, 2019). Diyarbakır Orgu Cheese, which has a geographical indication of boundaries in Diyarbakır province and its districts, is a delicious and visually different regional cheese type. The reputation of Diyarbakır Orgu cheese comes not only from the quality of the milk used in its production but also from the knowledge and experience passed down from generation to generation, as well as the seasonal temperature specific to Diyarbakır, affecting the flavor and aroma of the cheese.

Diyarbakır Orgu cheese is defined as a semi-hard cheese type that is scalded in high-temperature water after its curd is fermented, high in fat, less salty (if consumed fresh) and easily split into fibers. In the production of this cheese, freshly milked full-fat raw ewe's milk is mixed with some cow's milk and/or goat's milk and fermented using liquid yeast at $28-35{ }^{\circ} \mathrm{C}$ to coagulate for $60-90$ minutes. The curd is cut and the whey is completely removed and the curd is pressed and fermented at room temperature (80-180 minutes). Fermented curd is finely chopped and scalded in hot water $\left(75-90{ }^{\circ} \mathrm{C}\right.$ for $2-7$ minutes). Scalded curd is stretched in the form of a rope, knitted in the form of a typical braid (150-300 g), and left in brine for about 30 minutes, then filled into tin or plastic drums. Packaged cheese is served for consumption freshly or after being stored/matured at $4-6{ }^{\circ} \mathrm{C}$ for varying periods (approximately 3-6 months) (Hatipoğlu \& Celik, 2012).

Orgu cheese is of great importance in terms of nutrition, especially for the people of the region where it is produced. Orgu cheeses, which are served for consumption in Diyarbakır, are produced in relatively low hygienic conditions in small businesses that do not have modern technology and a closed family economy with traditional methods. Since there is no standard production and product composition in Orgu cheese production, products with different compositions and qualities can be offered for sale. Traditional Orgu Cheese, which does not have a standard production process, varies from producer to producer in terms of production material, production stages, and 
packaging material. These differences may often have negative effects and may not please the consumer. In this context, it is important to ensure standardization in production and sustain the production of our traditional products that reflect the culture of the region. In this study, it is aimed to contribute to the dairy industry by eliminating the deficiencies in the literature about Diyarbakır Orgu Cheese produced by traditional and industrial methods. There are similar studies on the subject, and these studies are mostly about the storage of Orgu cheese produced under controlled conditions and the analysis of the product as a result of storage (Çelik et al., 2006; Çelebi, 2011; Hatipoğlu, 2014). Also, researchers mostly determined the microbiological quality (Ozdemir et al., 1998; Aksu et al., 1999; Anar et al., 2000; Turkoglu et al., 2003; Vural et al., 2010), chemical properties (Akyuz et al., 1998; Aksu et al., 1999; Anar et al., 2000; Turkoglu et al., 2003; Çelik et al., 2006; Çelik \& Turkoglu, 2007; Çelebi, 2011; Hatipoğlu, 2014), production method (Demirci et al., 1991; Akyuz et al., 1998; Unsal, 1997; Çelik \& Turkoglu, 2007; Hatipoğlu \& Celik, 2012) and food safety (Hatipoğlu \& Celik, 2012; Hatipoğlu, 2014) of Orgu cheese.

In this study, some chemical, biochemical, mineral content, antioxidant, and antimicrobial activity analyzes were made in 15 traditional and industrial Orgu cheeses from different manufacturers and brands supplied from the market, and the comparison of both groups of cheeses was made. Thus, the comparison of the production methods of Diyarbakır Orgu Cheese has been provided and this is also aimed to be a preliminary source for future study.

\section{Materials and methods}

\subsection{Materials}

In this study, 15 traditional Diyarbakır Orgu cheeses from different producers were obtained from the cheese market in the central district of Bağlar in Diyarbakır as the research material. Also, 15 industrial Orgu cheese from different brands being sold in the markets of Turkey was gathered, and thus a total of 30 different samples of Orgu cheese were used in the research. Cheese samples were brought to laboratory in polyethylene bags, where they were ground and put in glass jars. The samples were kept at $4 \pm 1{ }^{\circ} \mathrm{C}$ during the analysis.

\subsection{Methods}

\section{Chemical analysis}

The dry matter amount of Orgu cheese was determined by drying the samples in a drying oven at $103-105^{\circ} \mathrm{C}$ for 3-4 hours. The total amount of nitrogen was determined by the Kjeldahl method. A digital pH meter (Hanna Instrument $\mathrm{pH}$ 211; Microprocessor $\mathrm{pH}$ meter, Germany) was used for determination of $\mathrm{pH}$ (Association of Official Analysis Chemists, 1990). Gerber method was used to determine the amount of fat. Titratable acidity (as a lactic acid), ash, and salt content of cheese samples were determined according to the methods described by Kurt et al. (2003).

\section{Biochemical analysis}

Water-soluble extracts of the cheese samples were prepared as described previously (Kuchroo \& Fox, 1982). These extracts were used in the determination of water soluble nitrogen (WSN), 12\% trichloroacetic acid soluble nitrogen (TCA-SN), $5 \%$ phosphotungstic acid soluble nitrogen (PTA-SN), total peholic compounds (TPC) and antioxidant activity. The lipolysis ratio was measured as ADV (Acid Degree Value) according to methods described by Case et al. (1985). WSN, TCA-SN, and PTA-SN ratio of cheese were analyzed as described previously (Butikofer et al., 1993).

\section{Mineral analysis}

The cheese samples were burned in an ashing furnace at $550^{\circ} \mathrm{C}$ for $16 \mathrm{~h}$ (International Dairy Federation, 1992). The ash was dissolved with $5 \mathrm{~mL}$ nitric acid on the heating plate and filtered using Whatman no: 41. Following the filtering process, the solution was diluted with $1 \mathrm{~N} \mathrm{HNO}_{3}$ and completed in $50 \mathrm{~mL}$ with $1 \mathrm{~N} \mathrm{HNO}_{3}$. The $\mathrm{Ca}, \mathrm{Mg}, \mathrm{K}, \mathrm{P}, \mathrm{Zn}, \mathrm{Fe}, \mathrm{Mn}$ and $\mathrm{Cu}$ content of the cheese samples were determined by ICP-OES (Thermo Scientific ICAP 6300 DUO, England). Also, blank samples were prepared by subjecting the above procedures.

\section{Total Phenolic Compounds (TPC)}

TPC of samples in water-soluble extracts was analyzed according to the Folin Ciocalteu method (Yemis et al., 2008). For this, $150 \mu \mathrm{L}$ of extract were mixed with $3 \mathrm{~mL}$ of $\mathrm{Na}_{2} \mathrm{CO}_{3}(2 \%)$ in a test tube and $150 \mu \mathrm{L}$ of Folin-Ciocalteu's reagent $(1: 1, \mathrm{v} / \mathrm{v}$ in water) was added to the tube. Then the mixture incubated for 45 minutes at room temperature in the dark. Subsequently, the absorbance of the reaction mixture was read at $765 \mathrm{~nm}$ in the spectrophotometer (UV Mini-1240, Shimadzu, Japan). The results are expressed as gallic acid equivalent (mg GAE/kg).

\section{Antioxidant activity}

\section{DPPH test}

The DPPH radical-scavenging activity of the extracts was determined as described previously (Brand-Williams et al., 1995). Firstly, $100 \mathrm{~mL}$ of water-soluble extracts was mixed with $2.4 \mathrm{~mL}$ of the freshly prepared DPPH solution in a test tube. After a $30 \mathrm{~min}$ incubation, the absorbance at $520 \mathrm{~nm}$ was read using a spectrophotometer. The results were calculated from the following formula: Inhibition of DPPH (\%) $=[1-(\mathrm{A} / \mathrm{A} 0)] \times 100$, where $\mathrm{A} 0$ is the absorbance of the blank and $\mathrm{A}$ is the absorbance of the test.

\section{TEAC test}

Firstly, 7.0 mM ABTS radical solution containing $2.45 \mathrm{mM}$ potassium persulfate was prepared and oxidized in water for at least 12-16 hours at room temperature in the dark to form an ABTS ${ }^{-+}$radical solution. Then, this radical solution was diluted with $80 \%$ ethanol to give $0.700 \pm 0.2$ absorbances at $734 \mathrm{~nm}$. It was taken $2.97 \mathrm{~mL}$ from diluted radical solution and mixed with $30 \mu \mathrm{L}$ of water-soluble extracts in a test tube. The mixture left in a dark place for $6 \mathrm{~min}$ and the absorbance was measured 
at $734 \mathrm{~nm}$ in a spectrophotometer. The same processes were performed for Trolox and antioxidant activity value was expressed as $\mathrm{mmol} / \mathrm{g}$ Trolox equivalent (Kirca \& Ozkan, 2007).

\section{Antimicrobial assay}

The antibacterial activity of water soluble extracts of cheese samples on Gram positive (Staphylococcus aureus ATCC 29213) and negative bacteria (Escherichia coli ATCC 11303) was determined by agar well diffusion method (National Committee for Clinical Laboratory, 1999). Water soluble extracts of cheeses were sterilized by filtration through $0.45 \mu \mathrm{m}$ membrane filter. Firstly, test organisms were inoculated in Mueller Hinton Broth (Oxoid) and incubated at $37 \pm 0.1^{\circ} \mathrm{C}$ for $24 \mathrm{~h}$. Following incubation, small amounts of bacterial colony was removed from fresh bacteria cultures and the density of bacterial suspensions was adjusted with sterile physiological solution against 0.5 Mc-Farland standard tubes. $100 \mu \mathrm{L}$ of prepared culture was spread on the Mueller-Hinton Agar and then $100 \mu \mathrm{L}$ of extract solution was impregnated into the wells of agar plates directly. The inoculated plates were incubated at $37^{\circ} \mathrm{C}$ for $24 \mathrm{~h}$. Subsequently, the diameter of inhibition zone was observed and determined in $\mathrm{mm}$. Ampicillin $(10 \mu \mathrm{g})$ and Tetracycline $(30 \mu \mathrm{g})$ discs were used as positive controls.

\section{Statistical analysis}

SPSS for Windows statistical software (SPSS, 1999) was used for all statistical analysis in this investigation. All data are showed as mean \pm standard error of means.

\section{Results and discussions}

\subsection{Chemical composition of Orgu cheeses}

The chemical properties of the 30 cheese samples analyzed are demonstrated in Table 1. In the cheese communique published by the Turkish Food Codex, the moisture content of Orgu cheese is reported to be $50 \%$ at the most (Turkey, 2015). In this context, the dry matter rates in Table 1 comply with the limit values in the communiqué. When the groups were evaluated within themselves, the difference between the samples was mostly determined in Orgu cheese samples produced by the traditional method. It can be seen that the average dry matter values of Orgu cheese samples produced by traditional and industrial methods are close to the values obtained in previous studies (Hatipoğlu, 2014; Anar et al., 2000). The difference between the dry matter values is thought to be caused by the composition of milk affected by the dairy animal and feeding conditions and the lack of certain standards in Orgu cheese production (rennet used, salt amount, prepared brine, ripening time).

It was observed that the fat concentration results obtained in some studies on Orgu cheese (Ozdemir et al., 1998; Hatipoğlu, 2014; Aksu et al., 1999; Turkoglu et al., 2003) were lower than the values we obtained in the study (Table 1). This situation is thought to be caused by the difference in the fat content of the milk depending on the type of milk used. Çelik et al. (2006) determined the results of the fat analysis in Orgu cheese samples produced by using $3.8 \%$ full-fat, $3 \%$ fat, and $2 \%$ fat pasteurized cow milk as $22.00 \%, 20.75 \%, 17.75 \%$, respectively. Since fat in cheese is one of the components that make up the dry matter, the increases and decreases of these two parameters are proportional. The decrease in the amount of dry matter during the ripening period also affects the oil amount. A second reason for this loss in the amount of fat during ripening is that the breakdown products formed as a result of the hydrolysis of the oils pass into the brine (Hatipoğlu, 2014).

The protein ratios of Orgu cheese samples are given in Table 1. The obtained data is higher than those obtained by Akyuz et al. (1998), while it is lower than the ones obtained by Hayaloglu (2009), and similar to other literature values (Ozdemir et al., 1998; Hatipoğlu, 2014; Çelik et al., 2001, 2006; Turkoglu et al. ., 2003). This difference between protein amounts can be explained by the effect of the packaging material on dry matter losses and the prolongation of storage time, and the passage of small molecules consisting of protein structures that are broken down as a result of proteolysis into the brine (Hatipoğlu, 2014; Kose, 2015). Yetismeyen et al. (1995) argued that the process of pasteurization was effective on substance losses, that is, it increased the amount of nitrogen remaining in the clot. When the average protein ratios of both groups examined in this study are considered, it is seen that the industrial type of Orgu cheese samples produced from pasteurized milk has a higher protein ratio than the traditional type Orgu cheese produced from raw milk.

The acidity in milk and dairy products is the total acidity value found like milk (phosphate, citrate, globulin, albumin, and carbon dioxide) and formed as a result of microorganisms and starter culture activities. The acidity that develops later in the production of cheese is formed as a result of ripening and the decomposition of lactose in the cheese into lactic acid as a result of the fermentation and the effect of the products formed during ripening (Inal, 1990). The titration acidity value of Dil cheese, which is similar to Orgu cheese in terms of production technique, was reported as the highest 1.0\% l.a. (Turkey, 2006). It is estimated that the difference between the data obtained in the study and the literature is caused by the starter culture and amount used, the type of milk used, the salt ratio, and the maturation time. Kose (2015) reported that increasing the salt ratio in cheese decreases acidity and increases $\mathrm{pH}$ value. It can be said that with the increase in the fat content of milk used in cheese production, the acidity in cheese decreases, and the $\mathrm{pH}$ increases (Çelik et al., 2006).

Free basic and neutral compounds, free organic acids, and protein-bound acidic and basic groups are groups that affect $\mathrm{pH}$ in cheese (Fox et al., 2000). On the other hand, Hatipoğlu (2014) reported the average $\mathrm{pH}$ as 5.57 in a study on Orgu cheese made from raw milk. In this study, it was determined that the average $\mathrm{pH}$ values of both groups of cheeses were higher when compared with the ones in the literature (Table 1). Also, these values were higher than some Brasilian (Serra da Canastra and Araxa cheeses) (Kamimura et al., 2019), Mexican (Adobera cheeses) (Ruvalcaba-Gómez et al., 2020) and Bosnia and Herzegovina (Livanjski cheeses) (Vladimír et al., 2020) cheeses. This difference is thought to be caused by the type of milk used, starter culture, packaging material, production methods and storage time. Also, ripeness levels of cheeses are thought to cause 
Table 1. The results of chemical analysis of Orgu cheeses.

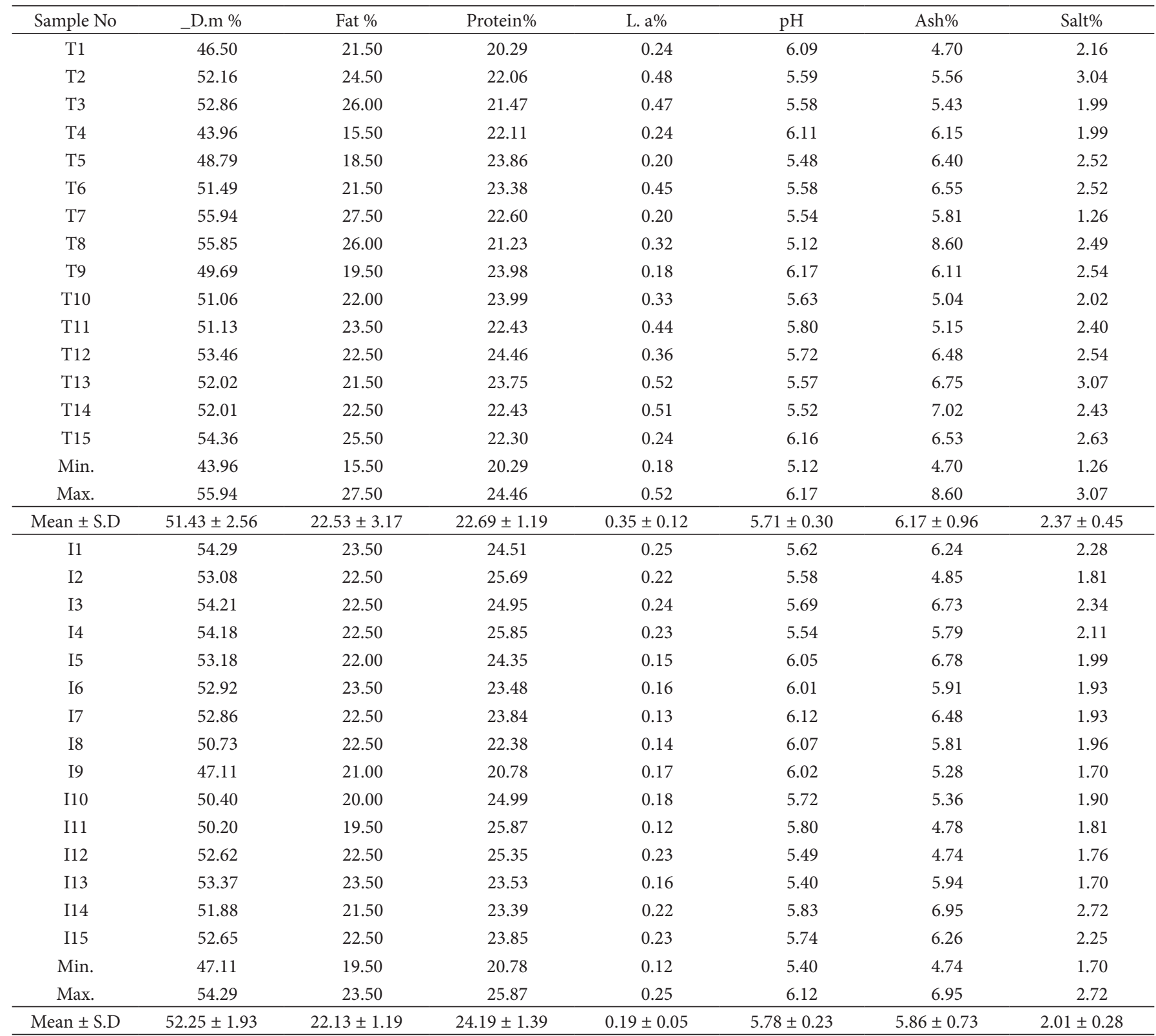

D.m: Dry matter; L.a: Lactic acid; T: Orgu cheese samples produced by the traditional method; I: Orgu cheese produced by the industrial method; S.D: Standard deviation.

differences in $\mathrm{pH}$ values. Kose (2015) found that the average $\mathrm{pH}$ values of Herby cheese, which produced experimentally, decreased during the ripening period over time. It is estimated that this situation is caused by the production of lactic acid and other organic acids by the effect of enzymes during maturation and the conversion of fats into free fatty acids with the existing lipase activity (Urkek, 2008).

In studies on Orgu cheese, Aksu et al. (1999) determined the average ash amount as $6.43 \%$, while Ozdemir et al. (1998) found it as $7.43 \%$, and Hatipoğlu (2014) determined as $8.77 \%$. While Çelik \& Turkoglu (2007) found the amount of ash between $7.09 \%$ and $8.22 \%$ in their experimental Orgu cheese samples made from raw milk, Çelebi (2011) found the amount of ash between $6.95 \%$ and $8.49 \%$ in Orgu cheese samples produced using different coagulating enzymes. The difference between the ash ratios of the cheese samples we evaluated in this study and the literature is thought to be due to the difference in the amount of salt in the cheese samples. Also, according to Tuncturk (1996), titration acidity and $\mathrm{pH}$ value of cheese samples affect the rate of salt taken into the cheese environment and this situation is directly reflected in the ash ratio.

Salt is a nutrient that adds flavor to the cheese, also increases the durability of the cheese, and affects the consistency and yield. Changing the salt ratio in cheese may decrease or increase depending on the habit of the producer and the consumer's request (Demir, 2008). Considering that the salt ratio allowed for curd scalded cheeses is at most 3\% in the Cheese Communiqué (Turkey, 2015), it is seen that the average salt ratio in cheese 
samples produced by traditional and industrial methods conforms to the standard (Table 1). It has been observed that the average salt ratio in different studies on Orgu cheese is generally higher than the results obtained in this study (Turkoglu et al., 2003; Celik et al., 2006; Celebi, 2011). It is thought that the amount of salt is affected by the salt ratio used in cheese making and the storage conditions. It was determined that the amount of salt in cheese samples kept in brine increased during storage (Yetismeyen et al., 1998; Çelik \& Turkoglu, 2007; Çelebi, 2011; Hatipoğlu, 2014). According to Guinee \& Fox (1987), in parallel with the increase in the moisture content of cheese, there is an increase in the salt movement towards the inner parts of the cheese. This increase is affected by factors such as the size of the cheese mold, acidity, and dry matter of the cheese, storage temperature, and time, and the longer the storage period, the higher the rate of salt transferred to the cheese.

\subsection{Biochemical composition of Orgu cheeses}

The biochemical properties of the 30 cheese samples analyzed are demonstrated in Table 2 . When the WSN rates obtained in the study are compared with the literature, it is seen that the results are generally quite high (Ozdemir et al., 1998; Çelik et al., 2006; Çelebi, 2011; Farkye et al., 1991). When the WSN rates obtained in the study are compared with the literature, it is seen that the results are generally quite high (Ozdemir et al., 1998; Çelik et al., 2006; Çelebi, 2011; Farkye et al., 1991). It is estimated that this is due to the type of milk used, storage time, salt concentration, and the type of enzyme used. In the study, WSN ratios of cheeses produced by traditional methods were found higher than those produced by industrial methods. This difference is thought to be caused by microorganisms with high proteolytic activity found in the natural flora of raw milk. Similarly, in the study conducted by Kose (2015), it was found that the WSN ratios of Herby cheeses produced from raw milk were higher than cheeses produced from pasteurized milk. It also stated that another factor affecting the level of proteolysis in cheese is the salt concentration and that the proteolysis rate of cheeses stored in vacuum packaging is higher than the proteolysis rate of cheeses stored in brine. This is attributed to the lower salt content of cheeses stored in vacuum packaging. Likewise, in some studies, it has been reported that increasing salt concentration in water-soluble nitrogen analyzes in cheese reduces the water-soluble nitrogen ratio (Cakmakçı \& Kurt, 1993; Kılıç \& Işın, 2004).

In Orgu cheeses that Celik et al. (2006) produced from cow milk with three different fat ratios, the nitrogen values dissolved in $12 \%$ TCA on average were found as $0.08 \%, 0.14 \%$, and $0.18 \%$. Yasar (2007) found the nitrogen solubility values between $0.05 \%$ and $0.14 \%$ in $12 \%$ TCA of Kashar cheeses produced by using different coagulating enzymes. Say (2008), in a study, reported the nitrogen solubility values of the Kashar cheese samples at $12 \%$ TCA in the range of $0.05 \%$ to $0.24 \%$. In a study conducted by Hatipoğlu (2014) on Orgu Cheese, the average value of soluble nitrogen at $12 \%$ TCA was given as $0.04 \%$. Some of the data obtained were consistent with the literature, while some were higher than previous studies (Table 2). It is estimated that rennet used, salt concentration, and storage time lead to this situation.
There are very small peptides and amino acids in the nitrogen fraction obtained by using nitrogen soluble in 5\% PTA. The rate of nitrogen soluble in 5\% PTA is important for determining the peptidase activity and ripening level in cheese (Tuncturk, 1996). It has been reported that there is a direct proportion between this nitrogen fraction and cheese flavor-aroma. (Demir, 2008). It was determined that the data obtained were higher than the literature values (Yasar, 2007; Say, 2008). This is thought to be due to the increase in cheese ripening levels, like other proteolysis parameters.

Average lipolysis values obtained in the study were found to be lower than $5.59 \mathrm{ADV}$ value which is the average lipolysis rate by Andic et al. (2010) in Herby cheese and higher than 0.96 ADV value, the average lipolysis rate obtained by Kose (2015) in a study on Herby cheese (Table 2). This situation is thought to be due to the different maturity and salt concentration of cheeses.

Collins et al. (2003) reported that especially lipases originating from lactic acid bacteria were adversely affected by salt. In a study in which cheese samples were stored in brine and vacuum packaged (Kose, 2015), the lower lipolysis value in cheese samples stored in brine indicates that the salt concentration has a negative effect on the lipolysis value. In another study, the inhibitory effect of high salt concentration in lipolysis occurring in Iranian pickled cheese and curd cheese was highlighted (Azarnia et al., 1997).

\subsection{Mineral content of Orgu cheese samples}

The mineral content of cheeses depends on various factors such as nutrition, genetics, lactation period, geographical area of milk production, environmental conditions, lack of a standard technique in cheese production, and possible contamination of equipment during cheese production (Altun \& Köse, 2016).

Sodium is important for the regulation of blood and osmotic pressure, the transport of water to and outside of the cells, and the transmission of nerve cell impulses (Cruz et al., 2011). However, excessive sodium intake causes high blood pressure and other chronic diseases (Felicio et al., 2013). When the values obtained in the study were compared with the literature (Ozdemir et al., 1998; Altun \& Köse, 2016; Kose \& Ocak, 2015), it was found that the results were close to some values and lower than others (Table 3). The main reason for this difference is the salt concentration of cheese samples and brine water. Demirci (1988) stated that salting forms of cheeses are effective in $\mathrm{Na}$ ratios, so Na ratios vary considerably in cheese types in the world.

The Ca content of Traditional and Industrial Orgu Cheese samples range between 1501.51 and $2015.44 \mathrm{mg} / 100 \mathrm{~g}$ (Table 3). When the data obtained were compared with the literature, it was found that the results were close to some values, higher than some, and lower than others (Çelebi, 2011; Demirci, 1988; Ozlu et al., 2012; Feeney et al, 2021). It is thought that this situation is caused by the storage method, storage period, packaging material, and the composition of the milk. It has been observed in some studies that $\mathrm{Ca}$ loss increases as the ripening period increases, and some minerals pass into brine water due to osmotic pressure, especially in cheeses preserved in brine. However, Ca loss, which is at high levels in the early stages of storage, decreases in the later stages (Guinee \& Fox, 1986; 
Table 2. The results of biochemical analysis of Orgu cheeses.

\begin{tabular}{|c|c|c|c|c|}
\hline Sample No & WSN\% & TCA-SN\% & PTA-SN\% & Lipolysis (ADV) \\
\hline $\mathrm{T} 1$ & 16.53 & 3.50 & 1.65 & 1.85 \\
\hline $\mathrm{T} 2$ & 14.91 & 6.69 & 2.16 & 0.65 \\
\hline $\mathrm{T} 3$ & 16.43 & 5.71 & 1.47 & 0.87 \\
\hline $\mathrm{T} 4$ & 18.82 & 4.33 & 1.51 & 2.57 \\
\hline T5 & 25.13 & 2.90 & 1.18 & 3.37 \\
\hline T6 & 12.83 & 4.12 & 1.28 & 1.77 \\
\hline T7 & 16.91 & 4.52 & 1.79 & 1.71 \\
\hline $\mathrm{T} 8$ & 22.55 & 5.95 & 2.62 & 4.55 \\
\hline T9 & 13.22 & 2.92 & 1.18 & 0.60 \\
\hline T10 & 11.00 & 2.96 & 0.87 & 1.08 \\
\hline T11 & 19.50 & 5.15 & 1.17 & 1.95 \\
\hline $\mathrm{T} 12$ & 12.83 & 3.47 & 0.65 & 1.05 \\
\hline $\mathrm{T} 13$ & 16.58 & 5.26 & 1.79 & 0.87 \\
\hline T14 & 25.99 & 5.84 & 1.63 & 0.84 \\
\hline $\mathrm{T} 15$ & 12.48 & 3.73 & 0.89 & 0.65 \\
\hline Min. & 11.00 & 2.90 & 0.65 & 0.60 \\
\hline Max & 25.99 & 6.69 & 2.62 & 4.55 \\
\hline Mean \pm S.D & $17.05 \pm 4.61$ & $4.47 \pm 1.24$ & $1.46 \pm 0.52$ & $1.62 \pm 1.13$ \\
\hline I1 & 15.95 & 3.49 & 0.64 & 1.53 \\
\hline I2 & 15.44 & 3.38 & 0.60 & 1.61 \\
\hline I3 & 14.62 & 2.56 & 0.69 & 1.08 \\
\hline $\mathrm{I} 4$ & 11.89 & 2.20 & 0.60 & 2.42 \\
\hline I5 & 10.50 & 2.62 & 0.56 & 0.53 \\
\hline I6 & 11.04 & 2.48 & 0.92 & 0.84 \\
\hline I7 & 10.77 & 2.11 & 0.82 & 0.81 \\
\hline I8 & 10.73 & 2.46 & 0.86 & 1.41 \\
\hline I9 & 15.64 & 3.04 & 1.24 & 1.18 \\
\hline I10 & 9.41 & 1.69 & 0.76 & 1.08 \\
\hline I11 & 8.05 & 1.22 & 0.67 & 0.52 \\
\hline $\mathrm{I} 12$ & 7.89 & 1.59 & 0.93 & 0.93 \\
\hline I13 & 6.04 & 1.96 & 1.01 & 0.82 \\
\hline I14 & 11.10 & 1.85 & 1.55 & 0.88 \\
\hline $\mathrm{I} 15$ & 9.58 & 1.72 & 1.80 & 0.83 \\
\hline Min. & 6.04 & 1.22 & 0.56 & 0.52 \\
\hline Max. & 15.95 & 3.49 & 1.80 & 2.42 \\
\hline Mean \pm S.D & $11.24 \pm 3.01$ & $2.29 \pm 0.66$ & $0.91 \pm 0.36$ & $1.10 \pm 0.49$ \\
\hline
\end{tabular}

WSN: water soluble nitrogen; TCA-SN: Trichloroacetic acid- soluble nitrogen; PTA-SN: Phosphotungstic acid- soluble nitrogen T: Orgu cheese samples produced by the traditional method; I: Orgu cheese produced by the industrial method; S.D: Standard deviation.

Kose \& Ocak, 2019). It has been determined that this situation is caused by the salt concentration between cheese moisture and brine water (Guinee \& Fox, 1986; Gider, 2006).

It can be understood from Table 3 that the $\mathrm{Mg}$ values of Orgu cheese are significantly higher than the previous research results (Ozdemir et al., 1998; Çelebi, 2011; Ozlu et al., 2012; Ocak \& Kose, 2015). In a study on Herby cheese (Kose \& Ocak, 2019), it appears that the $\mathrm{Mg}$ concentration decreases during storage over time, similar to the Ca content. It was reported that $70 \%$ of the $\mathrm{Mg}$ was in soluble form and that $\mathrm{Mg}$ was transferred from the cheese to the brine during the storage period until the osmotic pressure between the brine and the cheese phase is equalized. Also, it was determined that the Mg loss in cheeses kept in brine was higher than the loss in vacuum packaging.
Average K values of Orgu cheese samples in Table 3 were found to be higher than previous studies (Altun \& Köse, 2016; Kose \& Ocak, 2019; Ozlu et al., 2012). It is thought to be caused by dairy animals, geographical area of milk production, environmental conditions, possible contamination, and losses during the maturation period. In a study conducted by Kose \& Ocak (2019), a decrease in K was reported during storage. Also, it was reported that samples kept in brine were exposed to more K loss than vacuum-packed samples and this was due to the difference in salt concentration between the preservation methods.

Compared to previous studies, it is clear that the $\mathrm{P}$ content of Orgu cheeses is higher (Table 3). In a study by Demirci (1988) investigating the mineral content of many cheese varieties, the average $\mathrm{P}$ concentration in Kasar cheese was reported as 
Table 3. The results of mineral content of Orgu cheeses.

\begin{tabular}{|c|c|c|c|c|c|c|c|c|c|}
\hline Sample No & $\mathrm{Na}(\mathrm{mg} / 100 \mathrm{~g})$ & $\mathrm{Ca}(\mathrm{mg} / 100 \mathrm{~g})$ & $\mathrm{Mg}(\mathrm{mg} / 100 \mathrm{~g})$ & $\mathrm{K}(\mathrm{mg} / \mathrm{kg})$ & $\mathrm{P}(\mathrm{mg} / \mathrm{kg})$ & $\mathrm{Zn}(\mathrm{mg} / \mathrm{kg})$ & $\mathrm{Fe}(\mathrm{mg} / \mathrm{kg})$ & $\mathrm{Cu}(\mathrm{mg} / \mathrm{kg})$ & $\mathrm{Mn}(\mathrm{mg} / \mathrm{kg})$ \\
\hline $\mathrm{T} 1$ & 2592.17 & 1935.71 & 2313.67 & 2317.79 & 7981.30 & 82.80 & 5.04 & 7.88 & 4.38 \\
\hline $\mathrm{T} 2$ & 2548.42 & 1792.07 & 2271.23 & 2239.91 & 6643.13 & 67.36 & 4.82 & 4.56 & 1.25 \\
\hline T3 & 2499.70 & 1588.09 & 2243.24 & 2311.97 & 9216.21 & 61.10 & 6.43 & 3.79 & 1.18 \\
\hline $\mathrm{T} 4$ & 2467.49 & 1732.41 & 2224.72 & 2648.75 & 17738.99 & 88.73 & 4.67 & 3.23 & 1.40 \\
\hline $\mathrm{T} 5$ & 2343.61 & 1501.51 & 2104.98 & 1952.54 & 4856.27 & 42.61 & 5.45 & 4.08 & 0.95 \\
\hline T6 & 2484.54 & 1761.65 & 2239.34 & 2217.99 & 8336.54 & 74.35 & 4.72 & 6.36 & 0.97 \\
\hline T7 & 2488.07 & 1588.06 & 2128.86 & 2298.64 & 6887.47 & 56.60 & 5.48 & 4.27 & 0.94 \\
\hline $\mathrm{T} 8$ & 2587.82 & 1825.24 & 2224.37 & 2147.45 & 5800.68 & 47.66 & 6.34 & 3.71 & 1.27 \\
\hline T9 & 2499.21 & 1848.01 & 2139.93 & 2211.37 & 8094.93 & 59.68 & 7.13 & 3.12 & 1.14 \\
\hline T10 & 2416.85 & 1554.94 & 2170.80 & 2257.69 & 10318.35 & 65.40 & 8.02 & 5.09 & 1.43 \\
\hline T11 & 2475.50 & 1780.18 & 2220.24 & 2220.88 & 9883.49 & 58.01 & 8.25 & 4.74 & 1.38 \\
\hline $\mathrm{T} 12$ & 2489.44 & 1856.18 & 2238.45 & 2301.33 & 12404.69 & 64.92 & 4.45 & 4.71 & 1.17 \\
\hline T13 & 2500.16 & 1803.62 & 2236.00 & 2388.67 & 13126.81 & 78.30 & 5.20 & 4.38 & 1.48 \\
\hline T14 & 2472.23 & 1634.76 & 2145.66 & 2184.73 & 10070.58 & 77.84 & 5.75 & 4.61 & 1.22 \\
\hline $\mathrm{T} 15$ & 2511.65 & 1847.12 & 2234.08 & 2241.61 & 11755.57 & 57.85 & 6.40 & 5.19 & 1.31 \\
\hline Min. & 2343.61 & 1501.51 & 2104.98 & 1952.54 & 4856.27 & 42.61 & 4.45 & 3.12 & 0.94 \\
\hline Max & 2592.17 & 1935.71 & 2313.67 & 2648.75 & 17738.99 & 88.73 & 8.25 & 7.88 & 4.38 \\
\hline Mean \pm S.D & $\begin{array}{c}2491.79 \pm \\
60.93 \\
\end{array}$ & $\begin{array}{c}1736.64 \pm \\
130.74 \\
\end{array}$ & $\begin{array}{c}2209.04 \pm \\
58.09 \\
\end{array}$ & $\begin{array}{c}2262.76 \pm \\
145.43 \\
\end{array}$ & $\begin{array}{c}9541.00 \pm \\
3290.98 \\
\end{array}$ & $\begin{array}{c}65.55 \pm \\
12.89 \\
\end{array}$ & $5.88 \pm 1.20$ & $4.65 \pm 1.21$ & $1.43 \pm 0.83$ \\
\hline I1 & 2309.49 & 1795.93 & 2084.17 & 2003.56 & 9182.92 & 28.64 & 5.93 & 4.96 & 1.17 \\
\hline $\mathrm{I} 2$ & 2244.69 & 1645.31 & 2038.80 & 2112.85 & 12618.20 & 55.58 & 6.37 & 4.16 & 1.42 \\
\hline I3 & 2489.36 & 2015.44 & 2219.79 & 2297.77 & 15497.96 & 84.85 & 7.33 & 2.69 & 1.61 \\
\hline I4 & 2405.21 & 1847.08 & 2212.59 & 2262.95 & 13705.92 & 54.40 & 7.59 & 4.07 & 1.36 \\
\hline I5 & 2423.12 & 1647.75 & 2261.03 & 2399.58 & 13794.12 & 75.66 & 3.96 & 4.11 & 1.72 \\
\hline I6 & 2309.87 & 1942.81 & 2029.56 & 2477.37 & 18020.89 & 68.39 & 6.18 & 3.39 & 1.43 \\
\hline I7 & 2351.73 & 1634.29 & 2126.04 & 2469.60 & 17801.52 & 57.38 & 2.44 & 4.80 & 1.25 \\
\hline I8 & 2427.42 & 1607.73 & 2141.71 & 2291.61 & 16174.89 & 56.37 & 3.03 & 3.49 & 1.18 \\
\hline I9 & 2268.40 & 1608.96 & 2028.55 & 2333.80 & 16979.19 & 55.28 & 5.79 & 3.16 & 1.07 \\
\hline $\mathrm{I} 10$ & 2221.84 & 1535.17 & 1992.82 & 2077.19 & 13400.41 & 53.36 & 6.92 & 3.63 & 1.01 \\
\hline I11 & 2414.46 & 1858.21 & 2181.93 & 2055.77 & 10912.59 & 45.13 & 4.60 & 5.09 & 1.88 \\
\hline I12 & 2368.73 & 1862.04 & 2139.77 & 2288.21 & 20285.96 & 51.62 & 3.09 & 4.24 & 1.12 \\
\hline $\mathrm{I} 13$ & 2446.78 & 1786.42 & 2232.26 & 2485.39 & 20870.25 & 61.64 & 4.06 & 3.44 & 1.41 \\
\hline I14 & 2484.93 & 1820.11 & 2224.31 & 2334.23 & 18981.97 & 55.09 & 3.81 & 5.02 & 1.34 \\
\hline $\mathrm{I} 15$ & 2462.18 & 1850.39 & 2193.59 & 2342.86 & 20440.13 & 63.37 & 3.93 & 3.62 & 1.79 \\
\hline Min. & 2221.84 & 1535.17 & 1992.82 & 2003.56 & 9182.92 & 28.64 & 2.44 & 2.69 & 1.01 \\
\hline Max. & 2489.36 & 2015.44 & 2261.03 & 2485.39 & 20870.25 & 84.85 & 7.59 & 5.09 & 1.88 \\
\hline Mean \pm S.D & $\begin{array}{c}2375.21 \pm \\
87.16\end{array}$ & $\begin{array}{c}1763.84 \pm \\
140.91 \\
\end{array}$ & $\begin{array}{c}2140.46 \pm \\
87.16\end{array}$ & $\begin{array}{c}2282.18 \pm \\
155.31\end{array}$ & $\begin{array}{c}15911.13 \pm \\
3583.95\end{array}$ & $\begin{array}{c}57.78 \pm \\
12.84 \\
\end{array}$ & $5.00 \pm 1.68$ & $3.99 \pm 0.73$ & $1.38 \pm 0.27$ \\
\hline
\end{tabular}

T: Orgu cheese samples produced by the traditional method; I: Orgu cheese produced by the industrial method; S.D: Standard deviation.

$568 \mathrm{mg} / 100 \mathrm{~g}$. Ozdemir et al. (1998) reported the average P concentration in Orgu cheese as $368.74 \mathrm{mg} / 100 \mathrm{~g}$. On the other hand, Akalin (2011), in a study investigating the mineral content of some cheese varieties, reported that the $\mathrm{P}$ concentration ranged from $100 \mathrm{mg} / 100 \mathrm{~g}$ to $810 \mathrm{mg} / 100 \mathrm{~g}$.

Zinc is a normal component of cow's milk and zinc can be obtained from milk and its products in a form that can be easily used in the body (Kınık et al., 2001). Zn values of Orgu cheese obtained in the study are given in Table 3. It has been determined that these values are higher than some values obtained in previous studies while close to some values (Çelebi, 2011; Ozlu et al., 2012; Yuzbasi et al., 2009). It is estimated that this varies according to the storage period and the packaging used. As a matter of fact, in the study conducted by Kose \& Ocak (2019), it was determined that the $\mathrm{Zn}$ concentration decreased during storage and the cheeses kept in brine at the end of storage had lower $\mathrm{Zn}$ content than vacuum-packed cheeses.

Iron is an important trace element found as a catalyst in various metabolic reactions. Milk and dairy products are insufficient sources of Fe for human nutrition (Zamberlin et al., 2012). Its deficiency causes anemia, decreased immunity, and changes in mental development (Gaucheron, 2000). Iron (Fe) contents of the Orgu cheese samples produced by traditional and industrial methods were given in Table 3 . The results of the study are generally consistent with previous study results (Altun \& Köse, 2016; Kose \& Ocak, 2019; Yuzbası et al., 2009; Mendil, 2006).

In the human body, red blood cell formation, amino acid metabolism, and energy metabolism are based on copper. Cu content 
in uncontaminated milk is at the level of $0.02-0.05 \mathrm{mg} / \mathrm{kg}$. $\mathrm{Cu}$ catalyzes the oxidation of fat that causes oxidized taste in milk and its products in the presence of air. It also has a great influence on the acid formation and ripening speed of the cheese. Low $\mathrm{Cu}$ concentrations accelerate maturation (Kınık et al., 2001). According to Table 3, $\mathrm{Cu}$ amounts of Orgu cheese are between 2.69 and $7.88 \mathrm{mg} / \mathrm{kg}$ and are similar to the results of previous studies (Çelebi, 2011; Altun \& Köse, 2016; Kose \& Ocak, 2019; Ocak \& Kose, 2015). It is thought that possible contamination during cheese production will affect the $\mathrm{Cu}$ amount.

The Institute of Medicine recommends that manganese intake should not exceed a maximum daily limit of $11 \mathrm{mg} /$ day (NRC, 1989). In general, $\mathrm{Mn}$ is bound to the insoluble part of the casein micelle of milk with a rate of $95 \%$ (Cichoscki et al., 2002). As the $\mathrm{pH}$ in cheese decreases during ripening, $\mathrm{Mn}$ is expected to pass into a soluble form (Macedo \& Malcata, 1997). Thus, loss occurs in Mn content during maturation. Merdivan et al. (2004) reported that among the cheese groups they examined, the lowest amount of mineral matter in cheeses was seen in $\mathrm{Mn}$ values. By Macedo \& Malcata (1997), the Mn concentration of Serra cheese was reported as $1.17 \mathrm{mg} / \mathrm{kg}$ and $1.40 \mathrm{mg} / \mathrm{kg}$. Cichoscki et al. (2002) stated the Mn content for Prato cheese as 0.36 to $0.26 \mathrm{mg} / \mathrm{kg}$. Kose \& Ocak (2015) reported that the average amount of $\mathrm{Mn}$ in Surk cheese samples varied between $0.42 \mathrm{mg} / \mathrm{kg}$ and $1.20 \mathrm{mg} / \mathrm{kg}$. It was determined that the values obtained in the study were higher than some and close to others when compared with previous studies.

\subsection{TPC and antioxidant activity}

Antioxidants are defined as substances that greatly delay or prevent the oxidation of easily oxidizable materials in small quantities (MacDonald-Wicks et al., 2006). Therefore, the intake of antioxidants with foods plays an important role in preventing various diseases such as cancer and cardiovascular diseases and delaying the aging process (Albayrak et al., 2010). The total phenolic substance and antioxidant activity analysis results of the traditional and industrial Orgu cheese samples were shown in Table 4.

Phenolic compounds are acidic and plant origin compounds that are rarely isolated in cheeses. However, as a result of a protein or amino acid degradation of some microorganisms, phenolic compounds can also be formed (O'Connell \& Fox, 2001).

El-Tahra et al. (2015) reported that while the TPC of Domiati cheeses produced by adding different amounts of liquid incense and incense powder on the 90th day was $29.81 \mathrm{mg} / 100 \mathrm{~g}$, the TPC contents of goat's milk containing $0.4 \%, 0.5 \%$ and $0.6 \%$ liquid incense were respectively $42.15,54.64$ and $74.73 \mathrm{mg} / 100 \mathrm{~g}$. Kara (2019) also determined the average TPC as $647.72 \mathrm{mg}$ $\mathrm{GAE} / \mathrm{kg}$ in Herby cheeses matured with the brine method and $742.81 \pm 110.60 \mathrm{mg} \mathrm{GAE} / \mathrm{kg}$ in Herby cheeses ripened by pressing method. The values obtained in the current study are close to the results obtained by Kara (2019) and El Tahra et al. (2015). It is thought that factors such as some additives added to cheese, storage conditions, and maturity level of cheese affect the TPC.

Stable synthetic radicals DPPH and ABTS tests were used to determine the antioxidant activity of the Orgu cheese samples.
Both radicals take electrons and turn into non-radical derivatives when an antioxidant molecule is present in the environment. Species of these radicals, whose solutions are colored and absorb maximum in the wavelength region of $520(\mathrm{DPPH})$ and $734 \mathrm{~nm}$ (ABTS), in the presence of antioxidants do not absorb at these wavelengths. There is an inverse relationship between the abundance of antioxidants in the environment and the total radical concentration or absorbance (Dagdelen, 2010). Meira et al. (2012) claimed that antioxidant activity is linked to the increase in the number of peptides that occur as a result of proteolysis in cheese.

The most important feature of antioxidant substances is that they capture free radicals (Sanlıdere-Aloglu, 2010). DPPH method has been used in many studies to determine the antioxidant properties of bioactive peptides in cheese. DPPH inhibition values of Orgu cheese samples produced by traditional and industrial methods were given in Table 4. Meira et al. (2012) studied the antioxidant activities of sheep cheeses such as Roquefort, Pecorino, and Feta produced in Uruguay and Brazil. They reported that the radical inhibition rates of the peptides in terms of antioxidant activities varied between $38.49 \%$ and $51.84 \%$. Ozturk (2015) found the inhibition values obtained during ripening in Tulum cheese samples produced from cow and goat milk and matured for 120 days as $30.96 \%$ and $29.87 \%$, respectively. Kara (2019) reported the average DPPH inhibition value as $6.58 \%$ in herbal cheeses ripened with the brine method, and $8.35 \%$ in herbal cheeses ripened by the pressing method. It is estimated that the difference between the ripening levels of the cheeses and the storage conditions affect the antioxidant activity.

It has been reported that the method using ABTS •+ radical is more sensitive and suitable for determining the antioxidant activity of extracts dissolved in water (Gupta et al., 2009). TEAC values of the Orgu cheese samples produced by traditional and industrial methods are given in Table 4. Meira et al. (2012) studied the antioxidant activities of sheep cheeses such as Roquefort, Pecorino, and Feta produced in Uruguay and Brazil. He reported that according to the results of the antioxidant activity measurement of peptides, TEAC values varied between $0.74 \mathrm{mmol} \mathrm{TE} / \mathrm{g}$ and $2.02 \mathrm{mmol} \mathrm{TE} / \mathrm{g}$. Kara (2019) determined the average TEAC value of Herby cheeses ripened with the brine method as $1.15 \mathrm{mmol} \mathrm{TE} / \mathrm{g}$, and the average TEAC value of Herby cheeses ripened by the pressing method as $1.62 \mathrm{mmol}$ $\mathrm{TE} / \mathrm{g}$. The difference between the results is thought to be due to the maturation levels and storage conditions of the cheeses.

\subsection{Antimicrobial activity}

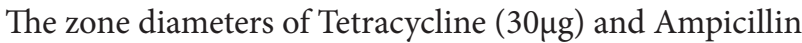
$(10 \mu \mathrm{g})$, which are used as positive controls in antimicrobial activity test, against Staphylococcus aureus ATCC 29213 were determined as 40 and $30 \mathrm{~mm}$, respectively. It was determined that Ampicillin $(10 \mu \mathrm{g})$ and Tetracycline $(30 \mu \mathrm{g})$ formed 20 and $19 \mathrm{~mm}$ zone diameters, respectively, against Escherichia coli ATCC 11303. It was determined that water-soluble extracts of Orgu cheese samples produced by both traditional and industrial methods did not show any antimicrobial activity against $E$. coli ATCC 11303 and S. aureus ATCC 29213. 
Table 4. The results of total phenolics and antioxidant activity of Orgu cheeses.

\begin{tabular}{|c|c|c|c|}
\hline Sample No & TPC (mg GAE/kg) & DPPH Inhibition \% & TEAC $(\mathrm{mmol} \mathrm{TE} / \mathrm{g})$ \\
\hline $\mathrm{T} 1$ & 775.29 & 4.77 & 3.12 \\
\hline $\mathrm{T} 2$ & 756.71 & 5.77 & 2.68 \\
\hline T3 & 887.43 & 5.40 & 4.46 \\
\hline $\mathrm{T} 4$ & 632.07 & 6.90 & 4.94 \\
\hline T5 & 855.64 & 5.14 & 3.35 \\
\hline T6 & 768.14 & 4.02 & 2.61 \\
\hline $\mathrm{T} 7$ & 1004.57 & 6.35 & 2.90 \\
\hline $\mathrm{T} 8$ & 1091.36 & 5.20 & 2.79 \\
\hline T9 & 764.21 & 6.22 & 3.61 \\
\hline $\mathrm{T} 10$ & 875.29 & 3.95 & 2.73 \\
\hline $\mathrm{T} 11$ & 700.29 & 6.02 & 3.18 \\
\hline $\mathrm{T} 12$ & 700.64 & 2.19 & 2.77 \\
\hline $\mathrm{T} 13$ & 774.57 & 4.72 & 2.39 \\
\hline $\mathrm{T} 14$ & 932.79 & 5.72 & 3.17 \\
\hline $\mathrm{T} 15$ & 648.14 & 5.16 & 3.13 \\
\hline Min. & 632.07 & 2.19 & 2.39 \\
\hline Max & 1091.36 & 6.90 & 4.94 \\
\hline Mean \pm S.D & $811.14 \pm 129.67$ & $5.17 \pm 1.16$ & $3.19 \pm 0.70$ \\
\hline I1 & 850.29 & 4.23 & 1.78 \\
\hline $\mathrm{I} 2$ & 729.93 & 7.01 & 2.36 \\
\hline $\mathrm{I} 3$ & 611.36 & 2.65 & 4.28 \\
\hline $\mathrm{I} 4$ & 930.29 & 3.88 & 3.25 \\
\hline I5 & 700.29 & 8.59 & 2.80 \\
\hline I6 & 732.07 & 4.77 & 2.76 \\
\hline I7 & 405.64 & 9.40 & 2.56 \\
\hline I8 & 568.50 & 7.62 & 3.57 \\
\hline I9 & 687.79 & 9.59 & 3.25 \\
\hline $\mathrm{I} 10$ & 848.14 & 5.89 & 1.69 \\
\hline I11 & 749.57 & 3.16 & 2.73 \\
\hline I12 & 361.71 & 7.85 & 1.66 \\
\hline $\mathrm{I} 13$ & 288.86 & 4.15 & 2.25 \\
\hline $\mathrm{I} 14$ & 645.29 & 6.26 & 2.45 \\
\hline $\mathrm{I} 15$ & 704.93 & 6.13 & 3.15 \\
\hline Min. & 288.86 & 2.65 & 1.66 \\
\hline Max & 930.29 & 9.59 & 4.28 \\
\hline Mean \pm S.D & $654.31 \pm 183.04$ & $6.08 \pm 2.24$ & $2.70 \pm 0.73$ \\
\hline
\end{tabular}

T: Orgu cheese samples produced by the traditional method; I: Orgu cheese produced by the industrial method; S.D: Standard deviation.

This study made it possible to evaluate the samples of both groups together and compare the two groups, besides examining the traditional and industrial Orgu cheeses separately. it was determined that the fat, ash, acidity, and salt ratios of group $\mathrm{T}$ cheeses were higher than group I cheeses. Also, the dry matter, $\mathrm{pH}$, and protein ratios of group I cheeses were higher than group $\mathrm{T}$ cheeses. These results highlight the importance of standardization in cheese making.

When the lipolysis, proteolysis, mineral content, total phenolic substance, and antioxidant activity of the cheese samples were examined, the group T Orgu cheeses had higher proteolysis and lipolysis rates than the group I Orgu cheeses. It is seen that vacuum packaging used in industrial type cheeses has a preventive effect on maturation parameters. The mineral content of both groups of Orgu cheese samples was very close. It is thought that the production method of Orgu cheeses produced by traditional and industrial methods does not make a difference in the mineral content. Also, it was found that the group T Orgu cheeses had a higher TFM than the group I Orgu cheeses, and their antioxidant activities were similar.

When the groups are examined within themselves, the standard deviation values calculated with the analysis results of the group $\mathrm{T}$ cheeses are generally high. This situation is thought to arise from the production method of group $\mathrm{T}$ cheeses. In the traditional method, although the final product composition differs from manufacturer to producer, it is seen that the production does not have a certain standard. The standard deviation values are generally lower in the industrial type Orgu cheese samples. 
Using quantitative measures in production, applied technological processes, and some additives, a standard is provided in the final product. Thus, products with similar chemical structures, close quality, and the same textural structure are obtained.

The effort to obtain a final product at certain standards and the same quality by using pasteurized milk and starter culture in more hygienic conditions in the production of industrial-type Orgu cheese has ensured that the values obtained as a result of the analysis are in a narrower range. Looking at the examples of traditional Orgu cheese, it is seen that the data obtained are in a very wide range. However, it is known that some mineral, proteolysis, and lipolysis and total phenolic contents of traditional Orgu cheeses are higher than industrial type Orgu cheese. In this context, it is important to transfer traditional Orgu cheese to the industry without losing its natural structure. For this purpose, sensory studies, which were previously carried out on different cheeses (Rodrigues et al., 2020, 2021; Soares et al., 2020; Torres et al., 2020) are needed in order to evaluate the consumer perceptions of Orgu cheese in different regions of Turkey.

\section{Conclusions}

This study can be regarded as a reference in terms of eliminating the deficiencies in the literature on the degree of proteolysis and lipolysis, total phenolic substance, antimicrobial and antioxidant activity of Orgu cheese. There are very few studies on Orgu cheese, and it can be seen that these studies are insufficient in terms of proteolysis and lipolysis degrees, the mineral substance, total phenolic substance, antimicrobial and antioxidant activities. More detailed and comprehensive studies are required to eliminate the deficiencies of this subject and to determine the effect of the Orgu cheese production method on these ingredients. Also, it can be suggested that in further studies, the effect of the Orgu cheese production method and different packaging materials on fatty acid composition, volatile composition, and organic acid content should be investigated.

\section{Acknowledgements}

This study was financially supported by the Coordination Unit of Scientific Research Projects of Van Yuzuncu Yil University, Project Number: FYL-2019-8175.

\section{References}

Akalin, A. S. (2011). Peynirin Beslenme ve Sağlık Etkisi, 16. In A. A. Hayaloğlu \& B. Özer (Eds.), Peynir Biliminin Temelleri (1. Baski). İzmir: Sidas Medya.

Aksu, H., Çolak, H., Vural, A., \& Erkan, M. E. (1999). Diyarbakır Bölgesinde üretilen Orgu peynirlerinin mikrobiyolojik ve kimyasal özellikleri üzerine bir araştırma. YYÜ Veteriner Fakültesi Dergisi, 10(1-2), 8-11.

Akyuz, N., Tutsi, M. F., Mengel, Z., Ocak, E., \& Altun, İ. (1998). Orgu peynirinin üretim tekniği, bazı mikrobiyolojik ve kimyasal özellikleri. In V. Süt ve Süt Ürünleri Sempozyumu, Süt Ürünleri (pp. 328-337). Ankara: Milli Prodüktivite Merkezi Yayınları.

Albayrak, S., Sağdıç, O., \& Aksoy, A. (2010). Bitkisel ürünlerin ve gıdaların antioksidan kapasitelerinin belirlenmesinde kullanılan yöntemler. Erciyes Üniversitesi Fen Bilimleri Enstitüsü Dergisi, 26(4), 401-409.
Altun, İ., \& Köse, Ş. (2016). Geleneksel Kelle peynirinin bazı özelliklerinin belirlenmesi. Yüzüncü Yil Üniversitesi Tarim Bilimleri Dergisi, 26(4), 642-647. http://dx.doi.org/10.29133/yyutbd.282843.

Anar, S., Soyutemiz, E., \& Çetinkaya, F. (2000). Orgu peynirinin üretim aşamalarında görülen bazı mikrobiyolojik ve kimyasal değişimler. Veteriner Fakültesi Dergisi, 19(1-2), 81-85.

Andic, S., Genccelep, H., \& Kose, S. (2010). Determination of biogenic amines in Herby cheese. International Journal of Food Properties, 13(6), 1300-1314. http://dx.doi.org/10.1080/10942910903061869.

Association of Official Analysis Chemists - AOAC. (1990). Official methods of analysis (15th ed.). Washington, DC: AOAC.

Azarnia, S., Ehsani, M. R., \& Mirhadi, S. A. (1997). Evaluation of the physico-chemical characteristics of the curd during the ripening of Iranian brine cheese. International Dairy Journal, 7(6-7), 473-478. http://dx.doi.org/10.1016/S0958-6946(97)00034-4.

Brand-Williams, W., Cuvelier, M. E., \& Berset, C. L. W. T. (1995). Use of a free radical method to evaluate antioxidant activity. LebensmittelWissenschaft + Technologie, 28(1), 25-30. http://dx.doi.org/10.1016/ S0023-6438(95)80008-5.

Butikofer, U., Ruegg, M., \& Ardö, Y. (1993). Determination of nitrogen fractions in cheese: evaluation of a collaborative study. Lebensmittel Wissenchaft und Technologie, 26(3), 271-275. http://dx.doi.org/10.1006/ fstl.1993.1056.

Cakmakçı, S., \& Kurt, A. (1993). Effect of salt amount of brine and ripening period, $\mathrm{CaCl}_{2}$ and lecithin addition made on white pickled cheese quality. Gida, 18(1), 21-28.

Case, R. A., Bradley, R. L., \& Williams, R. R. (1985). Chemical and physical methods. In G. H. Richardson (Ed.), Standard methods for the examination of dairy products (15th ed., pp. 327-404). Washington: American Public Health Association.

Çelebi, M. (2011). Farklı pıhtılaştırıcı enzimlerin olgunlaşma süresince orgu peynirinin özellikleri üzerine etkilerinin belirlenmesi. Isparta: Süleyman Demirel Üniversitesi Fen Bilimleri Enstitüsü.

Çelik, S., \& Turkoglu, H. (2007). Ripening of traditional Orgu cheese manufactured with raw or pasteurized milk: Composition and biochemical properties. International Journal of Dairy Technology, 60(4), 253-258. http://dx.doi.org/10.1111/j.1471-0307.2007.00344.x.

Çelik, S., Ozdemir, C., \& Ozdemir, S. (2001). Production techniques and some properties of traditional lavas cheese. The Journal of Biological Sciences, 1(7), 603-605. http://dx.doi.org/10.3923/jbs.2001.603.605.

Çelik, S., Turkoglu, H., \& Erdogan, A. (2006). Farklı oranlarda yağ içeren pastörize süt ile yapılan geleneksel Orgu peynirinin olgunlaşma periyodu boyunca bileşim ve bazı biyokimyasal özelliklerinin değişimi. In Gıda Kongresi (pp. 867-868). Bolu.

Cichoscki, A. J., Valduga, E., Valduga, A. T., Tornadijo, M. E., \& Fresno, J. M. (2002). Characterization of Prato cheese, a Brazilian semi-hard cow variety: evolution of physico-chemical parameters and mineral composition during ripening. Food Control, 13(4-5), 329-336. http:// dx.doi.org/10.1016/S0956-7135(02)00039-7.

Collins, Y. F., McSweeney, P. L. H., \& Wilkinson, M. G. (2003). Lipolysis and free fatty acid catabolism in cheese: a review of current knowledge. International Dairy Journal, 13(11), 841-866. http:// dx.doi.org/10.1016/S0958-6946(03)00109-2.

Cruz, A. G., Faria, J. A. F., Pollonio, M. A. R., Bolini, H. M. A., Celeghini, R. M. S., Granato, D., \& Shah, N. P. (2011). Cheeses with reduced content: effects on functionality, public health benefits and sensory properties. Trends in Food Science \& Technology, 22(6), 276-291. http://dx.doi.org/10.1016/j.tifs.2011.02.003. 
Dagdelen, S. (2010). Otlu peynire katılan önemli ot türlerinin antimikrobiyal, antioksidan özellikleri, aroma profili ve bazı kimyasal özelliklerinin belirlenmesi. Malatya: İnönü Üniversitesi Fen Bilimleri Enstitüsü.

Demir, T. (2008). Çirek peynirinin yapım ve bileşim özellikleri. Van: Van YYÜ Fen Bilimleri Enstitüsü.

Demirci, M. (1988). Ülkemizin önemli peynir çeşitlerinin mineral madde düzeyi ve kalori değerleri. Gida, 13(1), 17-21.

Demirci, M., Simsek, O., \& Tasan, M. (1991). Ülkemizde yapılan muhtelif tip peynirler. In 2. Milli Süt ve Ürünleri Sempozyumu. Tekirdag.

El-Tahra, M. A. A., İsmail, M. M., \& El-Metwally, R. I. (2015). Effect of adding smoke liquid or powder to goat's milk on some characteristics of Domiatti cheese. American Journal of Food Science and Nutrition Research, 2(2), 47-56.

Farkye, N. Y., Kıely, L. J., Allshouse, R. D., \& Kindstedt, P. S. (1991). Proteolysis in Mozzarella cheese during refrigerated storage. Journal of Dairy Science, 74(5), 1433-1438. http://dx.doi.org/10.3168/jds. S0022-0302(91)78300-8.

Feeney, E. L., Lamichhane, P., \& Sheehan, J. J. (2021). The cheese matrix: Understanding the impact of cheese structure on aspects of cardiovascular health: a food science and a human nutrition perspective. International Journal of Dairy Technology. In press. http://dx.doi.org/10.1111/1471-0307.12755.

Felicio, T. L., Esmerino, E. A., Cruz, A. G., Nogueira, L. C., Raices, R. S. L., Deliza, R., Bolini, H. M. A., \& Pollonio, M. A. R. (2013). Cheese, What is its contribution to the sodium intake of Brazilians. Appetite, 66, 84-88. http://dx.doi.org/10.1016/j.appet.2013.03.002. PMid:23500416.

Fox, P. F., Guinee, T. P., Cogan, T. M., \& Mcsweeney, P. L. H. (2000). Fundamentals of cheese science. Gaithersburg: Aspen Publishers.

Gaucheron, F. (2000). Iron fortification in dairy industry. Trends in Food Science \& Technology, 11(11), 403-409. http://dx.doi.org/10.1016/ S0924-2244(01)00032-2.

Gider, K. (2006). Beyaz peynirlerde tuz geçişini etkileyen bazı faktörlerin belirlenmesi. Konya: Selçuk Üniversitesi Fen Bilimleri Enstitüsü.

Guinee, T. P., \& Fox, P. F. (1986). Transport of sodium chloride and water in Romano cheese slices during brining. Food Chemistry, 19(1), 49-64. http://dx.doi.org/10.1016/0308-8146(86)90127-5.

Guinee, T. P., \& Fox, P. F. (1987). Salt in cheese: physical, chemical and biological aspects. In P. F. Fox (Ed.), Cheese: chemistry, physics and microbiology (pp. 251-297). London: Elsevier Applied Science, .

Gupta, A., Mann, B., Kumar, R., \& Sangwan, R. B. (2009). Antioxidant activity of Cheddar cheeses at different stages of ripening. International Journal of Dairy Technology, 62(3), 339-347. http:// dx.doi.org/10.1111/j.1471-0307.2009.00509.x.

Hatipoğlu, A. (2014). Geleneksel Diyarbakır Orgu peynirinin karakteristik özelliklerinin tespit edilmesi ve gıda güvenliği açısından değerlendirilmesi. Şanlıurfa: Harran Üniversitesi Fen Bilimleri Enstitüsü.

Hatipoğlu, A., \& Celik, S. (2012). Diyarbakır İli Karacadağ Havzasında üretilen geleneksel peynirler ve karșılașılan sorunlar. In 3. Geleneksel Gidalar Sempozyumu. Konya.

Hayaloglu, A. A. (2009). Volatile composition and proteolysis in traditionally produced mature Kashar cheese. International Journal of Food Science \& Technology, 44(7), 1388-1394. http://dx.doi. org/10.1111/j.1365-2621.2009.01968.x.

Inal, T. (1990). Süt ve Süt Ürünleri Hijyen ve Teknolojisi. İstanbul: Final Ofset.

International Dairy Federation - IDF. (1992). Trace elements in milk and milk products (Bulletin of the International Dairy Federation, No. 278). Brussels: IDF.
Kamber, U. (2005). Geleneksel Anadolu Peynirleri (223 p.). Ankara: Miki Matbaacılık.

Kamimura, B. A., Magnani, M., Luciano, W. A., Campagnollo, F. B., Pimentel, T. C., Alvarenga, V. O., Pelegrino, B. O., Cruz, A. G., \& Sant'Ana, A. S. (2019). Brazilian artisanal cheeses: an overview of their characteristics, main types and regulatory. Comprehensive Reviews in Food Science and Food Safety, 18(5), 1636-1657. http:// dx.doi.org/10.1111/1541-4337.12486. PMid:33336917.

Kara, S. (2019). Geleneksel yöntemle üretilen otlu peynirlerin bazı kalite özelliklerinin ve biyoaktivitesinin belirlenmesi. Van: VAN YYÜ Fen Bilimleri Enstitüsü.

Kılıç, M., \& Işın, T. G. (2004). Effect of salt level and storage on texture of Dil cheese. Journal of Texture Studies, 35(3), 251-262. http://dx.doi. org/10.1111/j.1745-4603.2004.tb00836.x.

Kınık, Ö., Uysal, H., \& Akbulut, N. (2001). Süt ve süt ürünlerinde iz elementler. İzmir: Ege Üniversitesi.

Kirca, A., \& Ozkan, M. (2007). Değișik Amaçlı Bazı Test ve Analiz Yöntemleri. 11. In B. Cemeroğlu (Ed.), Gıda Analizleri (No. 34). Ankara: Gıda Teknolojisi Derneği Yayınları.

Kose, S. (2015). Otlu peynire katılan bazı otların peynirin antimikrobiyal özellikleri, antioksidan kapasitesi ve fenolik bileşikleri üzerine etkisi. Van: Van Yüzüncü Yıl Üniversitesi Fen Bilimleri Enstitüsü.

Kose, S., \& Ocak, E. (2015). Geleneksel Sürk peynirinde bazı karakteristik özelliklerin belirlenmesi. Akademik Gıda, 13(2), 135-139.

Kose, S., \& Ocak, E. (2019). Mineral composition of Herby cheese produced from raw and pasteurized milk. Applied Ecology and Environmental Research, 17(3), 71897201. http://dx.doi.org/10.15666/ aeer/1703_71897201.

Kuchroo, C. N., \& Fox, P. F. (1982). Soluble nitrogen in Cheddar cheese: comparison of extraction procedures. Milk Science International, $37,331-335$

Kurt, A., Cakmakcı, S., \& Caglar, A. (2003). Süt Mamülleri Muayene ve Analiz Metotları Rehberi (8. Baskı, Yay. No. 252-D). Erzurum: Atatürk Üniversitesi Yayınları.

MacDonald-Wicks, L. K., Wood, L. G., \& Garg, M. L. (2006). Methodology for the determination of biological antioxidant capacity in vitro: a review. Journal of the Science of Food and Agriculture, 86(13), 20462056. http://dx.doi.org/10.1002/jsfa.2603.

Macedo, A. C., \& Malcata, F. X. (1997). Changes of mineral concentrations in Serra cheese during ripening and throughout the cheesemaking season. Journal of the Science of Food and Agriculture, 74(3), 409-415. http://dx.doi.org/10.1002/(SICI)1097-0010(199707)74:3<409::AIDJSFA821>3.0.CO;2-P.

Meira, S. M. M., Daroit, D. J., Helfer, V. E., Corrêa, A. P. F., Segalin, J., Carro, S., \& Brandelli, A. (2012). Bioactive peptides in water-soluble extracts of ovine cheeses from Southern Brazil and Uruguay. Food Research International, 48(1), 322-329. http://dx.doi.org/10.1016/j. foodres.2012.05.009.

Mendil, D. (2006). Mineral and trace metal levels in some cheese collected from Turkey. Food Chemistry, 96(4), 532-537. http://dx.doi. org/10.1016/j.foodchem.2005.03.006.

Merdivan, M., Yilmaz, E., Hamamc1, C., \& Aygun, R. S. (2004). Basic nutrients and element contents of white cheese of Diyarbakır in Turkey. Food Chemistry, 87(2), 163-171. http://dx.doi.org/10.1016/j. foodchem.2003.11.002.

National Committee for Clinical Laboratory Standard - NCCLS. (1999). M100-S9: performance standards for antimicrobial susceptibility testing. Wayne, PA: NCCLS.

National Research Council - NRC. (1989). Recommended dietary allowances (10th ed.). Washington, DC: National Academic Press. 
O'Connell, J. E., \& Fox, P. F. (2001). Significance and applications of phenolic compounds in the production and quality of milk and dairy products: a review. International Dairy Journal, 11(3), 103-120. http://dx.doi.org/10.1016/S0958-6946(01)00033-4.

Ocak, E., \& Kose, S. (2015). Van Otlu peynirinin üretimi ve mineral madde içeriği. Gida, 40(6), 343-348.

Ozdemir, S., Celik, S., Ozdemir, C., \& Sert, S. (1998). Diyarbakırın Karacadağ yöresinde mahalli olarak yapılan Orgu peynirinin mikrobiyolojik ve kimyasal özellikleri. In V. Süt ve Süt Ürünleri Sempozyumu Geleneksel Süt Ürünleri (pp. 154-166). Ankara: Milli Prodüktivite Merkezi Yayınları.

Ozlu, H., Atasever, A. M., Urcar, S., \& Atasever, M. (2012). Erzurum'da Tüketime Sunulan Kaşar Peynirlerinin Mineral Madde İçeriği ve Ağır Metal Kontaminasyonu. Kafkas Üniversitesi Veteriner Fakültesi Dergisi, 18(2), 205-208.

Ozturk, I. H. (2015). Geleneksel yöntemle üretilen Tulum peynirlerinin bazı kalite özelliklerinin, biyoaktif peptid içeriklerinin ve fonksiyonel özelliklerinin belirlenmesi. Konya: Selçuk Üniversitesi Fen Bilimleri Enstitüsü.

Rodrigues, J. F., Siman, I. B., Oliveira, L. E. A., Fátima Barcelos, A., Oliveira, R. A. A., Silva, R., \& Cruz, A. G. (2021). Use of diaries as a research strategy on sensory perception and consumer behavior of Canastra cheese. Journal of Sensory Studies, 36(2), e12627. http:// dx.doi.org/10.1111/joss.12627.

Rodrigues, J. F., Mangia, B. A., Silva, J. G., Lacorte, G. A., Coimbra, L. O., Esmerino, E. A., Freitas, M. Q., Pinheiro, A. C. M., \& Cruz, A. G. (2020). Sorting task as a tool to elucidate the sensory patterns of artisanal cheeses. Journal of Sensory Studies, 35(3), e12562. http:// dx.doi.org/10.1111/joss.12562.

Ruvalcaba-Gómez, J. M., Ruiz-Espinosa, H., Arteaga-Garibay, R. I., Rojas-López, M., Amador-Espejo, G. G., Anaya-Esparza, L. M., \& Delgado-Macuil, R. J. (2020). Texture, physicochemical and sensory properties of artisanal Adobera cheese from Los Altos de Jalisco, a genuine Mexican cheese. International Journal of Dairy Technology, 73(2), 411-420. http://dx.doi.org/10.1111/1471-0307.12676.

Sanlıdere Aloglu, H. (2010). Yoğurttan biyoaktif peptit eldesi ve bu peptitlerin antimikrobiyal ve antioksidan aktivitelerinin belirlenmesi. Isparta: Süleyman Demirel Üniversitesi Fen Bilimleri Enstitüsü.

Say, D. (2008). Haşlama suyunun tuz konsantrasyonu ve depolama süresinin kaşar peynirinin özellikleri üzerine etkileri. Adana: Çukurova Üniversitesi Fen Bilimleri Enstitüsü.

Soares, E. K. B., Silva, R., Silva, W. P., Kuriya, S. P., Maçaira, P. M., Cyrino Oliveira, F. L., Silva, M. A. A. P., Pimentel, T. C., Freitas, M. Q., Cruz, A. G., \& Esmerino, E. A. (2020). An intra-cultural investigation in Brazil using Coalho cheese and preferred attribute elicitation. Journal of Sensory Studies, 35(1), e12543. http://dx.doi. org/10.1111/joss.12543.

SPSS. (1999). SPSS for Windows Release 10.0. Chicago, IL: SPSS Inc.

Torres, F. R., Sılva, H. L. A. D., Cutrim, C. S., \& Cortez, M. A. S. (2020). Consumer perception of Petit-Suisse cheese: identifying market opportunities for the Brazilian dairy industry. Food Science and
Technology, 40(2, Suppl 2), 653-660. http://dx.doi.org/10.1590/ fst.38319.

Tuncturk, Y. (1996). Kaşar peynirinin starter kültür, proteinaz ve lipaz enzimleri ilavesiyle hızlı olgunlaştırılması üzerinde bir araştırma. Van: Van YYU Fen Bilimleri Enstitüsü.

Turkey. (2006). TS 3002: dil peyniri standardi. Ankara: Türk Standartları Enstitüsü.

Turkey. (2015, February 8). Türk Gıda Kodeksi Peynir Tebliği. Tebliğ No: 2015/6. Resmî Gazete, 29261. Retrieved from https://www. resmigazete.gov.tr/eskiler/2015/02/20150208-16.htm

Turkey. (2019). Türk Patent Enstitüsü tescilli coğrafi işaretler. Ankara: Türk Patent Enstitüsü. Retrieved from https://www.turkpatent.gov. tr/TURKPATENT/geographicalRegisteredList/

Turkoglu, H., Ceylan, Z. G., \& Dayısoylu, K. S. (2003). The microbiological and chemical quality of Orgu cheese produced in Turkey. Pakistan Journal of Nutrition, 2(2), 92-94. http://dx.doi.org/10.3923/ pjn.2003.92.94.

Unsal, A. (1997). Süt Uyuyunca-Türkiye Peynirleri. İstanbul: Yapıkredi Yayınları.

Urkek, B. (2008). Homojenizasyon ve ambalajlama işleminin Kaşar peynirinin bazı kimyasal, biyokimyasal, elektroforetik, duyusal ve mikrobiyolojik özelliklerine etkisi. Van: Van YYU Fen Bilimleri Enstitüsü.

Vladimír, D., Miloslava, K., Markéta, M., Jaroslava, H., \& Petr, R. (2020). Microbial diversity of Livanjski cheese with the emphasis on lactic acid bacteria based on culture-dependent and sequencing method. International Journal of Dairy Technology, 73(1), 202-214. http:// dx.doi.org/10.1111/1471-0307.12638.

Vural, A., Erkan, M. E., \& Güran, H. Ş. (2010). Orgu peyniri örneklerinde mikrobiyolojik kalitenin incelenmesi. Kafkas Üniversitesi Veteriner Fakültesi Dergisi, 16, 53-58.

Yasar, K. (2007). Farklı pıhtılaştırıcı enzim kullanımının ve olgunlaşma süresinin Kaşar peynirinin özellikleri üzerine etkisi. Adana: Çukurova Üniversitesi Fen Bilimleri Enstitüsü.

Yemis, O., Bakkalbasi, E., \& Artık, N. (2008). Antioxidant activities of grape (Vitis vinifera) seed extracts obtained from different varieties grown in Turkey. International Journal of Food Science \& Technology, 43(1), 154-159. http://dx.doi.org/10.1111/j.1365-2621.2006.01415.x.

Yetismeyen, A., Cimer, A., Ozer, M., Odabasi, S., \& Deveci, O. (1998). Ultrafiltrasyon tekniği ile salamura Beyaz Peynir üretiminde kalite üzerine değişik maya enzimlerinin etkisi. Gida Teknolojisi Dergisi, 23(1), 3-9.

Yetismeyen, A., Osmanlıoglu, M. A., \& Kaptan, B. (1995). Beyaz peynir sütüne uygulanan pastörizasyon normlarının teleme ve peynir altı suyu niteliklerine etkisi. Gida, 20(6), 371-382.

Yuzbası, N., Sezgin, E., Yıldırım, Z., \& Yıldırım, M. (2009). Changes in $\mathrm{Pb}, \mathrm{Cd}, \mathrm{Fe}, \mathrm{Cu}$ and $\mathrm{Zn}$ levels during the production of Kasar Cheese. Journal of Food Quality, 32(1), 73-83. http://dx.doi.org/10.1111/j.17454557.2007.00167.x.

Zamberlin, S., Antunac, N., Havranek, J., \& Samaržija, D. (2012). Mineral elements in milk and dairy products. Mljekarstvo, 62(2), 111-125. 